\title{
STUDIES ON THE BIOSYNTHESIS OF CLAVULANIC ACID
}

\section{INCORPORATION OF DL-[3,4- $\left.{ }^{13} \mathrm{C}_{2}\right]$ GLUTAMIC ACID}

\author{
S. W. Elson and R. S. Oliver* \\ Beecham Pharmaceuticals, Research Division, \\ Brockham Park, Betchworth, Surrey, RH3 7AJ, United Kingdom \\ B. W. ByCROFt and E. A. FARUK* \\ Department of Chemistry, University of Nottingham, \\ University Park, Nottingham, NG7 2RD, United Kingdom
}

(Received for publication October 26, 1981)

The role of glutamate in clavulanic acid biosynthesis was investigated by feeding DL-[3,4$\left.{ }^{13} \mathrm{C}_{2}\right]$ glutamate to a Streptomyces clavuligerus fermentation. The DL- $\left[3,4-{ }^{13} \mathrm{C}_{2}\right]$ glutamate was synthesised by reacting $\left[2{ }^{13} \mathrm{C}\right]$ diethylmalonate with $O$-tosyl- $N$-benzoyl- $\left[3-{ }^{13} \mathrm{C}\right]$ dehydroserine ethyl ester, which in turn was synthesised by condensing $\left[{ }^{13} \mathrm{C}\right]$ ethylformate with $N$-benzoylglycine ethyl ester. ${ }^{13} \mathrm{C}$ NMR examination of the benzyl clavulanate derived from the fermentation revealed the predicted labelling of carbons 2 and 8 with accompanying ${ }^{13} \mathrm{C}-{ }^{13} \mathrm{C}$ spin-spin coupling. Other enrichments and couplings were observed which could be explained by metabolism of the labelled glutamate via the tricarboxylic acid cycle to give further clavulanic acid precursors. These results confirm that glutamate provides the oxazolidine carbon skeleton as predicted by previous experiments.

Clavulanic acid ${ }^{12}$ is a $\beta$-lactam antibiotic produced by Streptomyces clavuligerus which possesses marked inhibitory activity against many bacterial $\beta$-lactamases ${ }^{2}$. Previous studies on the biosynthesis of clavulanic acid indicated that glutamate might provide the carbon skeleton for carbons 10, 3, 2, 8 and 9 of clavulanic acid ${ }^{3)}$. To investigate this possibility further, a sample of $\left[3,4-{ }^{13} \mathrm{C}_{2}\right]$ glutamate (VI) was chemically synthesised via the route shown in Scheme 1.

Examination of VI by ${ }^{13} \mathrm{C}$ NMR showed the expected ${ }^{13} \mathrm{C}$ - ${ }^{13} \mathrm{C}$ spin-spin coupling between $\mathrm{C}-3$ and

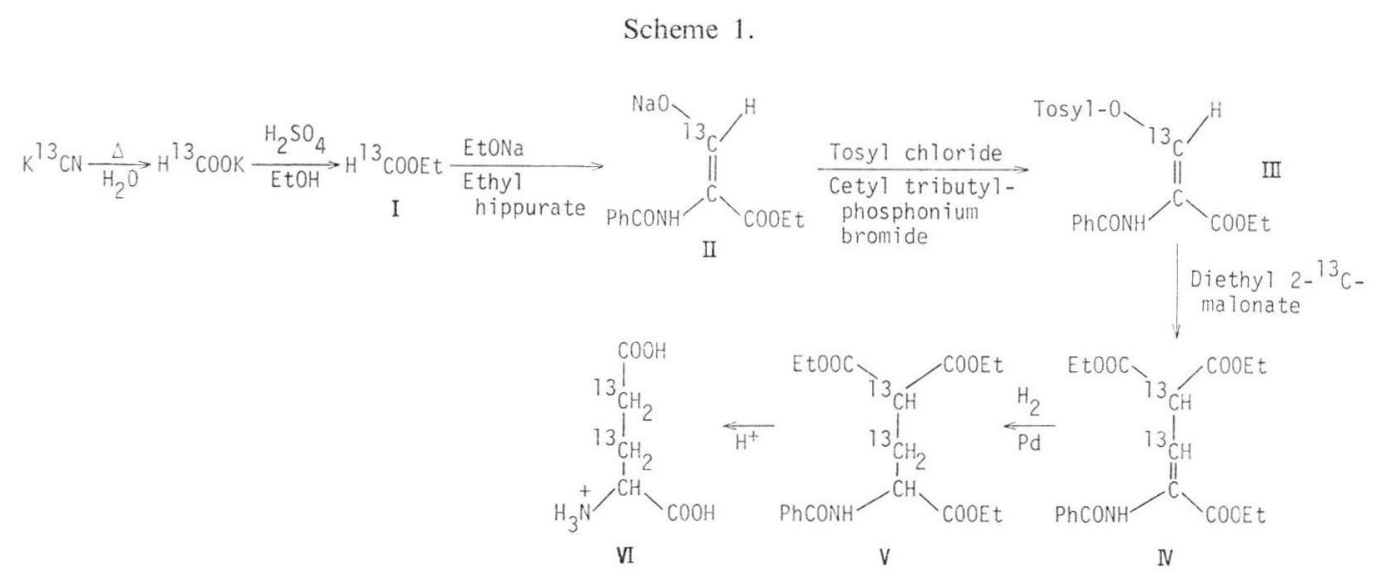

* Present addresses: Beecham Pharmaceuticals Research Division, Medicinal Research Centre, Coldharbour Road, The Pinnacles, Harlow, Essex, CM19 5AD, United Kingdom. 
Fig. 1. Clavulanic acid.

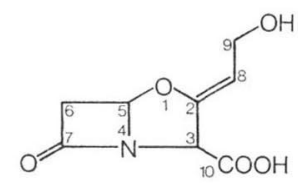

Scheme 2.

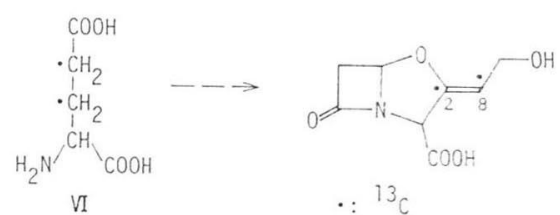

Fig. 2. ${ }^{13} \mathrm{C}$ NMR spectrum of ${ }^{13} \mathrm{C}$ enriched benzyl clavulanate.

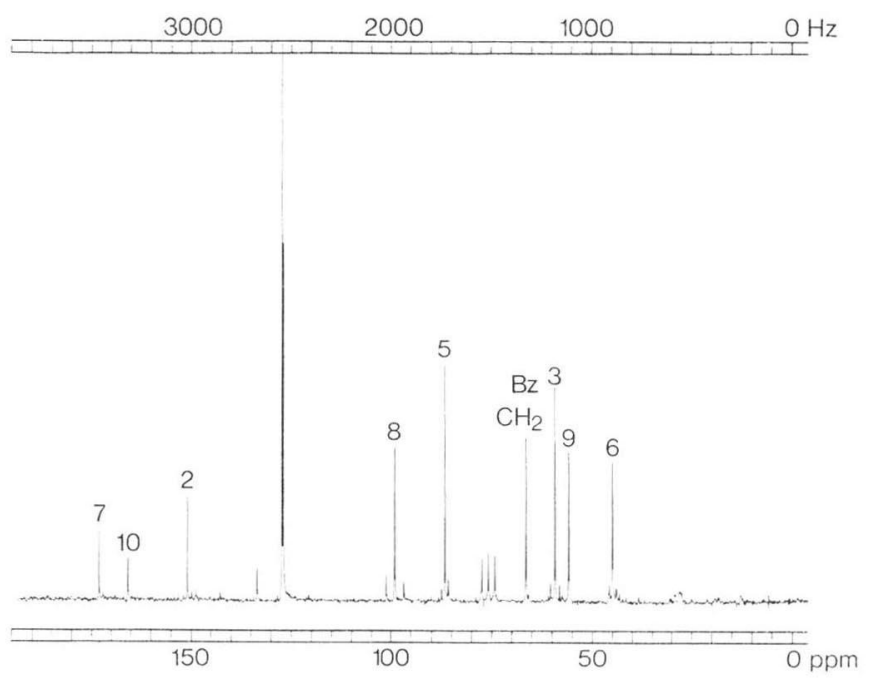

Table $1 .{ }^{13} \mathrm{C}$-Labelling of clavulanic acid derived from $\mathrm{DL}-\left[3,4-{ }^{13} \mathrm{C}_{2}\right]$ glutamate.

\begin{tabular}{|c|c|c|c|}
\hline Carbon & Enrichment ratio & $\begin{array}{l}\text { Enrichment as } \% \text { of } \\
\text { natural abundance }\end{array}$ & Analysis of enrichments \\
\hline 9 & 0.95 & Not significant & No couplings detected \\
\hline 8 & 1.28 & $28 \%$ & $\begin{array}{l}2 \% \text { not coupled } \\
26 \% \text { coupled to } \mathrm{C}-2\end{array}$ \\
\hline 2 & 1.92 & $92 \%$ & $\begin{array}{l}29 \% \text { coupled to C-8 } \\
40 \% \text { not coupled } \\
23 \% \text { coupled to } C-3\end{array}$ \\
\hline 3 & 1.42 & $42 \%$ & $\begin{array}{l}21 \% \text { coupled to } \mathrm{C}-2 \\
9 \% \text { not coupled } \\
12 \% \text { coupled to } \mathrm{C}-10\end{array}$ \\
\hline 10 & 0.95 & Not significant & no couplings detected \\
\hline 5 & 1.25 & $25 \%$ & $\begin{array}{l}3 \% \text { not coupled } \\
22 \% \text { coupled to C- } 6\end{array}$ \\
\hline 6 & 1.43 & $43 \%$ & $\begin{array}{l}27 \% \text { coupled to C-5 } \\
16 \% \text { not coupled }\end{array}$ \\
\hline 7 & 1.03 & Not significant & no couplings detected \\
\hline
\end{tabular}

C-4 $\left({ }^{1} J_{13} \mathrm{C}_{-13} \mathrm{C}=34.6 \mathrm{~Hz}\right)$ which was consistent in magnitude with the theoretical 82.7 double labelled molecules per cent.

VI (100 mg) was fed to a $S$. clavuligerus fermentation during the clavulanic acid production phase. The resulting clavulanic acid was isolated as the benzyl ester, the ${ }^{13} \mathrm{C}$ NMR spectrum of which is shown in Fig. 2. Examination of this spectrum revealed the presence of ${ }^{13} \mathrm{C}-{ }^{13} \mathrm{C}$ spin-spin couplings between 
Scheme 3 .

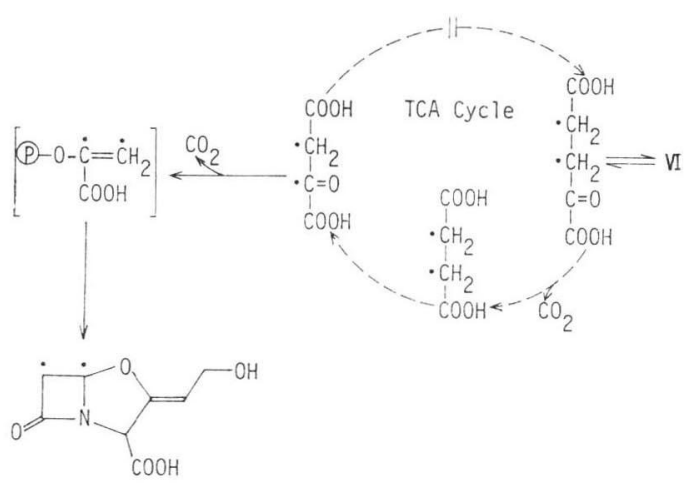

Scheme 4.

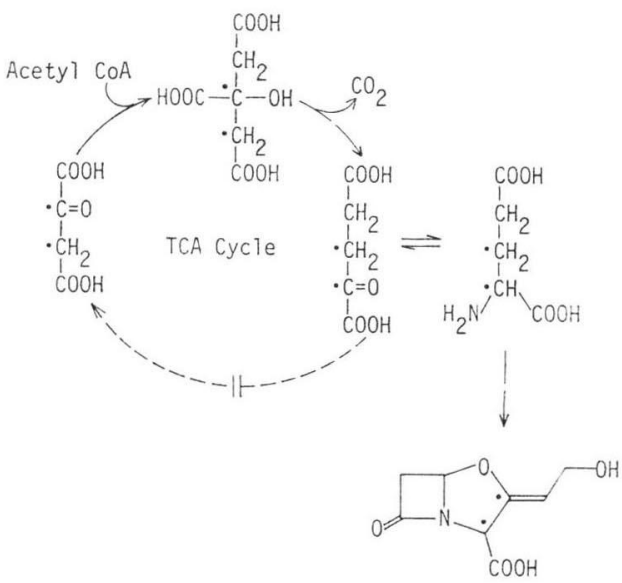

the following pairs of atoms: C-8 and C-2 $\left({ }^{1} J^{13} \mathrm{C}-1^{13} \mathrm{C}=87.2 \mathrm{~Hz}\right), \mathrm{C}-2$ and $\mathrm{C}-3\left({ }^{1} J^{13} \mathrm{C}-{ }^{13} \mathrm{C}=42.4 \mathrm{~Hz}\right), \mathrm{C}-3$ and $\mathrm{C}-10\left({ }^{1} J_{13} \mathrm{C}-{ }^{18} \mathrm{C}=67.0 \mathrm{~Hz}\right)$ and $\mathrm{C}-5$ and $\mathrm{C}-6\left({ }^{1} J^{1{ }^{3}} \mathrm{C}-{ }^{13} \mathrm{C}=33.7 \mathrm{~Hz}\right)$. The levels of ${ }^{13} \mathrm{C}$-enrichment were calculated by comparison with a natural abundance spectrum. These data are presented in Table 1 .

The direct incorporation of the intact carbon skeleton of VI into clavulanic acid, as shown in Scheme 2, would explain the observed coupling between C-8 and C-2. The remaining ${ }^{13} \mathrm{C}$-enrichments and couplings can be explained on the basis of deamination of VI to $\left[3,4-{ }^{13} \mathrm{C}_{2}\right]-\alpha$-ketoglutarate, followed by metabolism via the tricarboxylic acid (TCA) cycle and gluconeogenesis. The roles of these pathways in clavulanic acid biosynthesis have been described previously ${ }^{3)}$. Scheme 3 shows how the three $\beta$-lactam carbons can be generated from VI through the postulated intermediate phosphoenolpyruvate. This route would account for the coupling observed between C-5 and C-6. Further metabolism of the labelled oxaloacetate round the TCA cycle would result in the formation of $\left[2,3-{ }^{13} \mathrm{C}_{2}\right]-\alpha$-ketoglutarate and hence $\left[2,3-{ }^{13} \mathrm{C}_{2}\right]$ glutamate. Incorporation of this ${ }^{13} \mathrm{C}$-labelled species into clavulanic acid would explain the observed coupling between $\mathrm{C}-2$ and C-3. This route is illustrated in Scheme 4. Further metabolism of the ${ }^{13} \mathrm{C}$-labelled TCA cycle intermediates as above would predict labelling of C-5, C-6 and C-7 with a coupling between C-6 and C-7, which was not in fact observed, and labelling of C-2, C-3 and C10 , with a coupling between $\mathrm{C}-3$ and $\mathrm{C}-10$ which was observed. Any subsequent metabolism via the TCA cycle would then yield only non-coupled ${ }^{13} \mathrm{C}$-enrichments due to ${ }^{13} \mathrm{C}-{ }^{13} \mathrm{C}$ bond breakage.

The incorporation of VI into clavulanic acid therefore offers further support that glutamic acid supplies the carbon skeleton for carbons $10,3,2,8$ and 9 of clavulanic acid. The retention of ${ }^{13} \mathrm{C}-{ }^{13} \mathrm{C}$ spin-spin coupling between carbons 2 and 8 rules out the possibility that the hydroxyethylidene side chain is attached as a separate 2 carbon precursor to the clavam nucleus after the oxazolidine ring is closed. The observation of a coupling between C-2 and C-3 indicates metabolism via the "classic" TCA cycle rather than via the glyoxalate pathway. Obviously at some stage during clavulanic acid biosynthesis the $\gamma$-carboxyl group of glutamic acid must be reduced to hydroxymethyl. Conversely, carbons 3 and 4 of glutamic acid are at a lower oxidation level than the corresponding carbons in clavulanic acid. Our future studies on clavulanic acid biosynthesis will be aimed at attempting to elucidate the intermediates involved in these changes in oxidation levels. 


\section{Experimental}

General

${ }^{1} \mathrm{H}$ NMR $100 \mathrm{MHz}$ spectra were recorded with tetramethylsilane as internal reference. Mass spectra were determined with an A.E.I. MS9 high resolution spectrometer. Melting points were determined with a Koffler hot stage apparatus and are uncorrected.

${ }^{13}$ C-Enriched chemicals were obtained from Prochem, B.O.C. Ltd. U.K.

Preparation of $\left[3,4-{ }^{13} \mathrm{C}_{2}\right]$ Glutamic Acid Hydrochloride

The synthesis of VI was carried out following the route outlined in Scheme 1. Before the ${ }^{13} \mathrm{C}$ labelled synthesis was attempted, the route was followed using unlabelled materials when the authenticity of each intermediate was confirmed by spectral characteristics. During the labelled synthesis described below the intermediates were not always fully characterized. In these cases, spectral data for the unlabelled compounds are shown in addition to any data aquired for the labelled compounds. The methods of synthesis of the ${ }^{13} \mathrm{C}$-labelled and non-labelled compounds were essentially the same. Further details of the synthesis will be published (BYCROFT et al. in preparation).

(1) Ethyl ${ }^{13} \mathrm{C}$-Formate (I)

A solution of ${ }^{13} \mathrm{C}-\mathrm{KCN}(91.3$ atom $\% ; 1.0 \mathrm{~g})$ in $\mathrm{H}_{2} \mathrm{O}(5 \mathrm{ml})$ was heated in a sealed Carius tube at $140^{\circ} \mathrm{C}$ for 3 days. The tube was cooled, carefully opened, and the solution purged with nitrogen to remove dissolved $\mathrm{NH}_{3}$. The solution was evaporated in vacuo and the residual salt dried under high vacuum. The resulting white hygroscopic solid $(1.3 \mathrm{~g})$ was quickly broken up and treated with cold concentrated $\mathrm{H}_{2} \mathrm{SO}_{4}(1 \mathrm{ml})$ in dry EtOH $(2 \mathrm{ml})$. The mixture was left at room temperature with occasional swirling for 18 hours, then distilled by stirring and warming in an oil bath, collecting the distillate in a receiver cooled in ice-water. The major fraction of bp. $54 \sim 60^{\circ} \mathrm{C}$ was collected $(1.18 \mathrm{~g})$ which contained $26 \%$ EtOH (estimated from NMR spectrum), representing a true yield of $0.87 \mathrm{~g}(76 \%)$. This was used

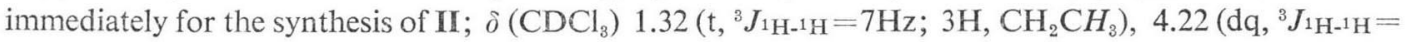
$\left.7 \mathrm{~Hz},{ }^{3} J^{13} \mathrm{C}-{ }^{1} \mathrm{H}=4 \mathrm{~Hz}, 2 \mathrm{H}, \mathrm{CH}_{2} \mathrm{CH}_{3}\right), 8.04\left(\mathrm{~d},{ }^{1} J^{1{ }^{3} \mathrm{C}-{ }^{1} \mathrm{H}}=224 \mathrm{~Hz}, \mathrm{ca} 1 \mathrm{H}, \mathrm{H}^{13} \mathrm{CO}\right)$; a singlet $(\mathrm{ca} 10 \%$ by integration) due to the ${ }^{12} \mathrm{C}$ analogue was also present at $\delta 8.04\left(\mathrm{H}^{12} \mathrm{CO}\right)$.

(2) Sodium Salt of Ethyl $N$-Benzoyl-2,3-dehydro-[3-13 C]serine (II) ${ }^{4}$

Ethyl ${ }^{13} \mathrm{C}$-formate $(0.86 \mathrm{~g} ; 11.5 \mathrm{mmole})$ was added to a stirred and cooled solution of sodium $(0.27 \mathrm{~g}$; 11.7 mmole) in dry EtOH $(5 \mathrm{ml})$. The mixture was stirred for 15 minutes and then crystalline ethyl hippurate $(2.48 \mathrm{~g} ; 12.0$ mmole) added over 20 minutes. The mixture was stirred for 40 hours, diluted with $\mathrm{Et}_{2} \mathrm{O}(20 \mathrm{ml})$, and poured into a large volume of $\mathrm{Et}_{2} \mathrm{O}(200 \mathrm{ml})$. The mixture was stirred for 30 minutes and filtered under suction through coarse (Whatman No. 41) filter paper. The product was quickly air dried, broken up and dried under high vacuum to give II as a white solid (2.08 g, $70 \%$ ). For non-labelled II: $\nu_{\max }(\mathrm{KBr}) 3400,1630,1610,1560,1530,1360,1290,1165$ and $1110 \mathrm{~cm}^{-1} ; \delta\left(\mathrm{D}_{2} \mathrm{O}\right) 1.28$ $\left(\mathrm{t}, J=7 \mathrm{~Hz}, 3 \mathrm{H}, \mathrm{CH}_{2} \mathrm{CH}_{3}\right), 4.17\left(\mathrm{q}, J=7 \mathrm{~Hz}, 2 \mathrm{H}, \mathrm{CH}_{2} \mathrm{CH}_{3}\right), 7.36 \sim 7.64(\mathrm{~m}, 3 \mathrm{H}$, aryl- $H), 7.72 \sim 7.92(\mathrm{~m}$, $2 \mathrm{H}$, aryl $-H), 8.46(\mathrm{~s})$ and $8.70(\mathrm{~s})(1 \mathrm{H}, \mathrm{C}=\mathrm{CH}, 25: 75)$.

(3) Ethyl (Z)-N-Benzoyl-O-tosyl-2,3-dehydro-[3-13 C]serine (III)

A solution of the sodium $\left[3-{ }^{13} \mathrm{C}\right.$ ]enolate (II) $(2.08 \mathrm{~g} ; 8.1 \mathrm{mmole})$ in $\mathrm{H}_{2} \mathrm{O}(20 \mathrm{ml})$ was added to a solution of recrystallized toluene-p-sulphonyl chloride $(1.53 \mathrm{~g} ; 8.0$ mmole $)$ in $\mathrm{CH}_{2} \mathrm{Cl}_{2}(40 \mathrm{ml})$ followed by a solution of cetyl tributylphosphonium bromide $(0.25 \mathrm{~g} ; 0.5$ mmole $)$ in $\mathrm{H}_{2} \mathrm{O}(5 \mathrm{ml})$. The mixture was stirred vigorously for 24 hours, the organic layer separated and the aqueous layer washed with further $\mathrm{CH}_{2} \mathrm{Cl}_{2}(20 \mathrm{ml})$. The $\mathrm{CH}_{2} \mathrm{Cl}_{2}$ solutions were combined, washed with $\mathrm{H}_{2} \mathrm{O}$, dried and evaporated to afford crude III which was crystallized from EtOAc-petroleum ether $40 \sim 60^{\circ} \mathrm{C}(1.88 \mathrm{~g}, 60 \%)$. m.p. $151 \sim 152^{\circ} \mathrm{C}$. For non-labelled III: m.p. $151 \sim 152^{\circ} \mathrm{C}$ (Found: C 58.78, H 5.21, N 3.48. $\mathrm{C}_{19} \mathrm{H}_{19} \mathrm{NO}_{6} \mathrm{~S}$ Calcd.: C 58.61, H 4.88, N 3.60\%), $\lambda_{\max }$ (EtOH) 260, 249 sh. and $229 \mathrm{~nm}$; $\nu_{\max }(\mathrm{KBr}) 3400,3300,1725$, $1655,1525,1497,1395,1290,1200,1183,1090,850,733$ and $720 \mathrm{~cm}^{-1} ; \delta\left(\mathrm{CDCl}_{3}\right) 1.28(\mathrm{t}, J=7 \mathrm{~Hz}, 3 \mathrm{H}$, $\mathrm{CH}_{2} \mathrm{CH}_{3}$ ), 2.45 (s, 3H, Ar- $\left.\mathrm{CH}_{3}\right), 4.27$ (q, $J=7 \mathrm{~Hz}, 2 \mathrm{H}, \mathrm{CH}_{2} \mathrm{CH}_{3}$ ), $7.30 \sim 7.60$ (m, 6H, aryl- $H$ NH), 7.59 $(\mathrm{s}, 1 \mathrm{H}, \mathrm{C}=\mathrm{CH}), 7.78 \sim 7.95\left(\mathrm{~m}, 4 \mathrm{H}\right.$, aryl-H); $\mathrm{m} / z 389\left(\mathrm{M}^{+}, 1 \%\right), 344$ (3), 234 (15), 218 (50), 217 (100), $189(10), 172(4), 155(8), 119(5)$ and $105(100)$. 
(4) Triethyl ( $Z$ )- $N$-benzoyl-4-carboxy-2,3-dehydro- $\left[3,4-{ }^{13} \mathrm{C}_{2}\right]$ glutamate (IV)

Sodium hydride ( $50 \%$ dispersion in oil, $0.3 \mathrm{~g} ; 6.2 \mathrm{mmole}$ ) was added gradually to a stirred solution of diethyl $\left[2{ }^{13} \mathrm{C}\right]$ malonate $(90.6$ atom $\%, 1.0 \mathrm{~g} ; 6.2 \mathrm{mmole})$ in anhydrous tetrahydrofuran $(20 \mathrm{ml})$ under a dry atmosphere. The mixture was stirred until evolution of $\mathrm{H}_{2}$ had ceased (4 hours) when crystalline III $(1.0 \mathrm{~g} ; 2.6$ mmole) was added over 2 minutes. The mixture was stirred for 3 hours, poured into EtOAc $(200 \mathrm{ml})$ and the solution washed with $\mathrm{H}_{2} \mathrm{O}$, brine, dried and evaporated to an oil which crystallized on addition of a little $\mathrm{Et}_{2} \mathrm{O}$ followed by petroleum ether $40 \sim 60^{\circ} \mathrm{C}$. The solid was washed with petrol to remove unreacted diethyl malonate and oil and dried to give crude IV $(0.735 \mathrm{~g})$. The aqueous washings and brine were combined, extracted with EtOAc $(3 \times 100 \mathrm{ml})$, the extracts combined, washed, dried and evaporated to give further IV $(0.280 \mathrm{~g})$ which was combined with the major crop and recrystallized from $\mathrm{Et}_{2} \mathrm{O}$ - petroleum ether $40 \sim 60^{\circ} \mathrm{C}$ to give pure IV $(0.73 \mathrm{~g}, 75 \%), \lambda_{\max }$ (EtOH) $253,244 \mathrm{sh}$. and 229 nm. m.p. $87 \sim 88^{\circ} \mathrm{C}$. For non-labelled IV: m.p. $87 \sim 88^{\circ} \mathrm{C}$ (Found: C 60.67, H 6.51, N 3.54. C C9- $^{-}$ $\mathrm{H}_{23} \mathrm{NO}_{7}$ Calcd.: C 60.48, H 6.10, N 3.71\%); $\lambda_{\max }$ (EtOH) 253, 244 sh. and $230 \mathrm{~nm}$; $\nu_{\max }(\mathrm{KBr}) 3400,3200$, $2950,1735,1715,1655,1320,1245,1205,1035$ and $710 \mathrm{~cm}^{-1} ; \delta\left(\mathrm{CDCl}_{3}\right) 1.20 \sim 1.44\left(\mathrm{~m}, 9 \mathrm{H}, \mathrm{CH}_{2} \mathrm{CH}_{3}\right)$, $4.16 \sim 4.44\left(\mathrm{~m}, 6 \mathrm{H}, \mathrm{CH}_{2} \mathrm{CH}_{3}\right), 4.64(\mathrm{~d}, J=9 \mathrm{~Hz}, 1 \mathrm{H}, \mathrm{C}=\mathrm{CH}-\mathrm{CH}), 6.88(\mathrm{~d}, J=9 \mathrm{~Hz}, 1 \mathrm{H}, \mathrm{C}=\mathrm{CH}-\mathrm{CH})$, $7.40 \sim 7.68(\mathrm{~m}, 3 \mathrm{H}$, aryl- $H), 7.84 \sim 8.00(\mathrm{~m}, 2 \mathrm{H}, \operatorname{aryl}-H), 8.30$ br $(1 \mathrm{H}, \mathrm{NH}) ; \mathrm{m} / z 377\left(\mathrm{M}^{+}, 4 \%\right), 332(6)$, 304 (3), 286 (1.5), 285 (2), 272 (4), 226 (2.5), 218 (100), 217 (6), 200 (3), 172 (10), 126 (3) and 105 (100).

(5) DL-Triethyl- $N$-benzoyl-4-carboxy-[3,4-13 $\left.\mathrm{C}_{2}\right]$ glutamate (V)

Crystalline IV $(731 \mathrm{mg})$ was dissolved in EtOH (35 ml) and 5\% Pd/C catalyst $(70 \mathrm{mg})$ added. The mixture was stirred under $\mathrm{H}_{2}$ for 20 hours when the reduction was complete as judged by UV absorption. The mixture was poured into $\mathrm{Et}_{2} \mathrm{O}(200 \mathrm{ml})$, stirred for 1 hour then filtered. The filtrate was evaporated to give $\mathbf{V}$ as a gum $\left(726 \mathrm{mg}, 99 \% \lambda_{\max }(\mathrm{EtOH}) 227 \mathrm{~nm}\right)$. For non-labelled $\mathbf{V}: \lambda_{\max }(\mathrm{EtOH}) 227 \mathrm{~nm}$; $\nu_{\max }$ (film) $3370,3000,1750,1740,1725,1660,1645,1540,1380,1340 \sim 1160 \mathrm{br}, 1100,1035,865,720$ and $700 \mathrm{~cm}^{-1} ; \delta\left(\mathrm{CDCl}_{3}\right) 1.12 \sim 1.40\left(\mathrm{~m}, 9 \mathrm{H}, \mathrm{CH}_{2} \mathrm{CH}_{3}\right), 2.28 \sim 2.88\left(\mathrm{~m}, 2 \mathrm{H}, \mathrm{CHCH}_{2} \mathrm{CHN}\right), 3.68(\mathrm{t}, J=7 \mathrm{~Hz}$, $1 \mathrm{H}, \mathrm{CHCH}_{2} \mathrm{CHN}$ ), $4.12 \sim 4.48\left(\mathrm{~m}, 6 \mathrm{H}, \mathrm{CH}_{2} \mathrm{CH}_{3}\right.$ ), 5.05 (dt, $J=5$ and $8 \mathrm{~Hz}, 1 \mathrm{H}, \mathrm{CH}_{2} \mathrm{CHNH}$ ), 7.32 br $(\mathrm{d}, J=8 \mathrm{~Hz}, 1 \mathrm{H}, \mathrm{N} H), 7.60 \sim 7.84(\mathrm{~m}, 3 \mathrm{H}$, aryl- $H), 8.00 \sim 8.20(\mathrm{~m}, 2 \mathrm{H}, \operatorname{aryl}-H) ; m / z 379\left(\mathrm{M}^{+}, 13 \%\right)$, 334 (22), 333 (5), 306 (100), 274 (34), 260 (17), 220 (14), 184 (100), 156 (28), 128 (28), $112(28)$ and 105 (100).

(6) DL- $\left[3,4-{ }^{13} \mathrm{C}_{2}\right]$ Glutamic Acid Hydrochloride (VI)

The saturated triester $(V)(726 \mathrm{mg})$ was refluxed with $5 \mathrm{~N} \mathrm{HCl}(50 \mathrm{ml})$ for 24 hours. The solution was cooled, diluted with $\mathrm{H}_{2} \mathrm{O}(20 \mathrm{ml})$ and extracted with EtOAc. The aqueous layer was evaporated to afford the crude DL-[3,4-13 $\left.\mathrm{C}_{2}\right]$ glutamic acid hydrochloride $(377 \mathrm{mg})$ as a white solid which was crystallized from a small volume of aqueous acetone at $0^{\circ} \mathrm{C}(293 \mathrm{mg}, 82 \%) .{ }^{13} \mathrm{C}$ NMR of VI diluted with approximately 100 parts non-labelled L-glutamic acid showed the following shifts: $\delta\left(\mathrm{D}_{2} \mathrm{O}\right) 27.6(\mathrm{C}-3), 34.1(\mathrm{C}-4)$, $55.3(\mathrm{C}-2), 175.3(\mathrm{C}-1), 181.9(\mathrm{C}-5) .{ }^{13} \mathrm{C}-{ }^{13} \mathrm{C}$ spin-spin coupling was observed between $\mathrm{C}-3$ and $\mathrm{C}-4$ $\left({ }^{1} J_{13} \mathrm{C}_{-13} \mathrm{C}=34.5 \mathrm{~Hz}\right)$. (Spectrum assigned according to HorSLEY et al..$\left.^{5)}\right)$. Ascending paper chromatography of VI (Whatman No. 1; solvent system: $n$-butanol - acetic acid - water, 4: $1: 5$ top phase) gave a ninhydrin positive spot at Rf 0.31 which was identical with authentic non-labelled L-glutamic acid when chromatographed both separately and in mixed chromatography. ${ }^{1} \mathrm{H}$ NMR (100 MHz) of a sample of non-labelled VI prepared through the above route was identical with authentic material.

\section{Fermentation}

The organism used for clavulanic acid production was Streptomyces clavuligerus SM 240. ${ }^{8)}$ The fermentation was performed as previously described ${ }^{3, \theta)}$ except that the volume of the medium was $800 \mathrm{ml}$. VI $(100 \mathrm{mg})$ was added to the fermentation at mid-production phase. Clavulanic acid was allowed to accumulate in the fermentation for a further 20 hours, then the mycelium was removed by centrifugation and the culture supernatant freeze dried.

\section{Isolation of Benzyl Clavulanate}

The freeze dried culture supernatant was reacted with benzyl bromide in dimethylformamide to produce crude benzyl clavulanate which was purified by column chromatography as described previously., ${ }^{3,}$ ) Yield: $106 \mathrm{mg}$ benzyl clavulanate as a pale gum. 
${ }^{13} \mathrm{C}$ NMR Spectroscopy

${ }^{13} \mathrm{C}$ NMR spectra were obtained of the labelled benzyl clavulanate and also a sample of unlabelled benzyl clavulanate using a Varian CFT20 spectrometer with a $5 \mathrm{~mm}$ probe. The samples were dissolved at the same concentration in deuterochloroform (approx. $1 \mathrm{M}$ ). Both spectra were run with identical spectrometer parameters. Chemical shifts were measured downfield from internal tetramethylsilane. Both spectra were run with square wave modulated broad band proton decoupling at ambient spectrometer temperature. All peaks, including satellites arising from ${ }^{13} \mathrm{C}-{ }^{13} \mathrm{C}$ coupling, were integrated. Levels of ${ }^{13} \mathrm{C}$-enrichment were calculated by comparing the integrals of the labelled sample with those of the unlabelled sample. As the benzyl ester group was added subsequent to incorporation of label, the benzyl methylene carbon was used as an internal natural abundance standard for the purpose of the comparison. The error of the enrichment ratios is estimated at about $\pm 5 \%$.

\section{Acknowledgements}

The authors are grateful to Miss A. StefansKa for expert assistance and Drs. M. Cole and A. G. Brown for helpful discussion.

\section{References}

1) Howarth, T. T.; A. G. Brown \& T. J. King: Clavulanic acid, a novel $\beta$-lactam isolated from Streptomyces clavuligerus: X-ray crystal structure analysis. J. Chem. Soc., Chem. Comm. 1976: 266 267, 1976

2) Reading, C. \& M. Cole: Clavulanic acid: A $\beta$-lactamase inhibiting $\beta$-lactam from Streptomyces clavuligerus. Antimicr. Agents \& Chemoth. 11: 852 857, 1977

3) Elson, S. W. \& R. S. Oliver: Studies on the biosynthesis of clavulanic acid. I. Incorporation of ${ }^{13}$ Clabelled precursors. J. Antibiotics 31: 586 592, 1978

4) Соoк, E.: Chemistry of Penicillin. p. 485, Princeton University Press, 1949

5) Horsley, W.; H. Sternlicht \& J. S. Cohen: Carbon-13 magnetic resonance studies of amino acids and peptides. II. J. Am. Chem. Soc. 92: 680 686, 1970

6) Stirling, I. \& S. W. Elson: Studies on the biosynthesis of clavulanic acid. II. Chemical degradations of ${ }^{14} \mathrm{C}$-labelled clavulanic acid. J. Antibiotics 32: 1125 1129, 1979 